\title{
UK local councils reporting of biodiversity values: a stakeholder perspective
}

\author{
Silvia Gaia (University of Essex) \\ Michael John Jones (University of Bristol)
}

\begin{abstract}
Purpose - This study explores the use of narratives in biodiversity reports as a mechanism to raise the awareness of biodiversity's importance. By classifying biodiversity narratives into 14 categories of biodiversity values this paper investigates whether the explanations for biodiversity conservation used by UK local councils are line with shallow, intermediate or deep philosophies.
\end{abstract}

Design/methodology/approach - This study used content analysis to examine the disclosures on biodiversity's importance in the biodiversity action plans published by UK local councils. The narratives were first identified and then allocated into 14 categories of biodiversity value. Then, they were ascribed to either shallow (resource conservation, human welfare ecology and preservationism), intermediate (environmental stewardship and moral extensionism) or deep philosophies.

Findings - UK local councils explained biodiversity's importance mainly in terms of its instrumental value, in line with shallow philosophies such as human welfare ecology and resource conservation. UK local councils sought to raise awareness of biodiversity' importance by highlighting values that are important for the stakeholders that are able to contribute towards biodiversity conservation such as landowners, residents, visitors, business and industries. We also found that local councils' biodiversity strategies were strongly influenced by 2010, the International Year of Biodiversity.

Originality/value - This paper is one of the few accounting studies that engages with the literature on environmental ethics to investigate biodiversity. In line with stakeholder theory, it indicates that explanations on biodiversity's importance based on anthropocentric philosophies are considered more effective in informing those stakeholders whose behaviour needs to be changed to improve biodiversity conservation.

Keywords - Biodiversity, Instrumental value, Intrinsic value, Local councils, Stakeholder theory, UK.

Paper type - Research paper 


\section{Introduction}

Biodiversity is the variety of all life found on the Earth. Species of plants, animals, microorganisms, the enormous diversity of genes in these species, the different ecosystems on the planet, are all part of a biologically diverse Earth. Biodiversity is important for its own sake and because human existence depends upon it (Norton, 1994). Although the importance of biodiversity has been emphasised from many perspectives, there is still a general lack of awareness of its importance (Union for Ethical BioTrade, 2016). This lack of awareness has been considered as one of the most serious barriers to biodiversity conservation (Convention on Biological Diversity, 2010). Human activities are causing plants and animals to go extinct. Neither does the rate of biodiversity loss seem to be slowing. International, national and local initiatives have been developed with the aim of promoting biodiversity conservation. The Convention on Biological Diversity, created and adopted by governments at the 1992 Earth Summit in Rio de Janeiro, set up, in 2010, a strategic plan. This aimed at reducing the loss of biodiversity, raising awareness of the importance of biodiversity conservation and developing a flexible framework to integrate biodiversity values into national and local strategies, accounting and reporting systems. To support and promote the implementation of the Strategic Plan of the Convention on Biological Diversity, the United Nations declared 20112020 as the Decade of Biodiversity and 2010 the Year of Biodiversity.

This study uses stakeholder theory to investigate the role played by Local Biodiversity Action Plans (hereafter LBAPs) to raise stakeholders' awareness of biodiversity's importance. It has the following main objectives. First, it shows how UK local councils use these strategic documents as communication tools to raise public awareness of biodiversity's importance. Second, it uses content analysis to identify the main arguments used to explain the importance of biodiversity. Third, it investigates whether these arguments are in line with the assumptions of either shallow, intermediate or deep philosophies.

As stressed by the Strategic Plan of the Convention on Biological Diversity (2010), to achieve biodiversity conservation it is pivotal that the strategies developed at (supra) national levels on biodiversity are adopted and implemented at local level. Local governments are key players in the preservation and management of biodiversity (Barut et al., 2016). They manage large public areas of land, much of which are rich in biodiversity. They are thus responsible for planning and regulating many activities which may impact on biodiversity. To address biodiversity loss concerns and to fulfil the international obligations under the Convention on 
Biological Diversity, local governments have been instructed to develop local strategies for biodiversity conservation (Convention on Biological Diversity, 2010). In the UK, in particular, since 1995, local councils have been encouraged to develop LBAPs as a means of ensuring that the national targets for biodiversity conservation are translated into local actions and as tools to raise awareness of the importance of biodiversity among the local stakeholders (UK Biodiversity Steering Group, 1995a).

According to stakeholder theory, the disclosure of information on biodiversity conservation strategies represents an important tool that local councils can use to discharge their accountability towards society and their stakeholders (Deegan, 2002). Local councils need to be accountable to society for the actions undertaken to conserve biodiversity as they act as stewards of the environment (Jones, 2003). They have a moral duty to maintain, enhance if possible, but certainly not deplete the world's natural resources for the sake of the environment and of current and future generations of human beings. Public sector accountability on environmental issues should ideally be based on a communitarian approach that places greater emphasis upon shared values and common concerns than upon the traditional individualist values (Burritt and Welch, 1997; Gray, 2010; Lehman 1999; Pallot, 1992). The adoption of a communitarian approach to accountability fosters stakeholder participation in the management of sustainability issues and is a way of advancing sustainability and environmental accounting (Gray, 2010; Lehman, 1999). Stakeholders who are aware of the importance of biodiversity are likely to avoid activities that can lead to biodiversity losses and adopt practices in line with biodiversity conservation, thus supporting the effective implementation of local biodiversity strategies (Convention on Biological Diversity, 2010). The potential stakeholders that local councils need to make aware of biodiversity's importance are heterogeneous and encompass several areas of the society (Schneider et al., 2014). As the interests and concerns of these stakeholders are likely to be different, different communication approaches need to be used to increase the awareness of biodiversity's importance, as the effectiveness of arguments might vary between the different stakeholder groups (Mueller and Maes, 2015).

The importance of biodiversity has been extensively examined within the literature on environmental ethics and different paradigms developed to explain the value of biodiversity. This study analyses the arguments used to explain biodiversity's importance by considering the environmental paradigms that capture much of the contemporary ethical debate on the 
relationships between human beings and nature (e.g. Buhr and Reiter, 2006; Connelly and Smith, 2003; Eckersley, 1992; Naess, 1973; Norton, 1994; Samkin et al. 2014; Sylvan and Bennett, 1994). They can be distinguished into (Sylvan and Bennett, 1994; Vincent, 1993): i) strong anthropocentric (shallow) paradigms which reject intrinsic value for biodiversity, but recognise that biodiversity has instrumental value to human beings; ii) weak anthropocentric (intermediate) paradigms which recognise the intrinsic value of some elements of nature but assign greater value to human beings; and iii) ecocentric (deep) paradigms which assign intrinsic value to biodiversity.

The remainder of this paper proceeds as follows. The next section illustrates the theoretical basis of our research questions focusing on the literature on biodiversity and environmental philosophies and reviewing prior research in the accounting discipline. Section 3 then explains the research context (the UK approach to biodiversity conservation and the role played by LBAPs). The research methods of the current study are set out in section 4. Section 5 then examines the environmental values used to explain the importance of biodiversity and explains their use with the theoretical underpinning of shallow, intermediate and deep philosophies. We then discuss our main findings using the lens of stakeholder theory in Section 6. The paper then concludes by illustrating the main contributions of the study and the venues for future research.

\section{Literature Review and Theoretical Framework}

\subsection{Biodiversity in the accounting discipline}

Accounting for biodiversity is an understudied research area (Jones and Solomon, 2013). Extensive accounting literature has focused on environmental and social accounting and reporting. By contrast, with few exceptions, accounting research has not generally acknowledged the importance of biodiversity. Some early work on this area was conducted before 2010, the year of biodiversity, in which Jones (1996, 2003) looked at alternative inventory models for recording, valuing and reporting biodiversity. More recently, biodiversity studies have tested biodiversity models (Khan, 2014; Siddiqui, 2013), looked at protected species (Atkins and Atkins, 2016) and investigated technical issues on the establishment of accountability mechanisms for biodiversity (Boiral and Heras-Saizarbitoria, 2017; Cuckston 2013; Tregidga 2013). Probably the most relevant works for this study are the studies that investigated biodiversity reporting (Atkins et al., 2014; Barut et al., 2016; 
Boiral, 2016; Rimmel and Jonäll, 2013; Samkin et al., 2014; Schneider et al., 2014, van Liempd and Busch, 2013).

Most of the studies on biodiversity reporting have investigated corporate disclosures. Rimmel and Jonäll (2013) used a legitimacy theory framework to analyse the quantity and motivation of biodiversity disclosure in 29 Swedish companies, finding limited disclosure. Similar results were found by Atkins et al. (2014) on UK and German listed firms' biodiversity disclosures and by van Liempd and Busch (2013) on Danish companies. Boiral (2016) investigated biodiversity reporting in mining organisations finding that companies released limited and biased biodiversity-related information. He questioned whether sustainability reports represent a reliable tool to evaluate organisations' biodiversity accountability. The first study that investigated biodiversity reporting by local councils was conducted in New Zealand by Schneider et al. (2014). They adopted a stakeholder accountability perspective to study the extent of biodiversity reporting and the way in which biodiversity information was communicated by 78 New Zealand local authorities. Their findings show that most local authorities did not discharge their accountability to stakeholders, suggesting the need for a framework to guide local authorities. Similar results were found by Barut et al. (2016) who investigated biodiversity disclosure in 151 local government authorities in Australia. Samkin et al. (2014) analysed the biodiversity-related disclosures in a New Zealand conservation organisation's annual reports over 23 years. Their findings showed that biodiversity-related information mostly reflected a deep ecological approach and were related to the implementation of biodiversity strategy/projects.

Our study aims to contribute to this literature by using stakeholder theory to analyse the use of biodiversity reporting as a tool to promote awareness of the importance of biodiversity.

\subsection{Public sector accountability and stakeholder theory}

Stakeholder theory explains environmental disclosure as a mechanism whereby organisations discharge their accountability to stakeholders (Deegan, 2002). In its broadest sense, accountability refers to the "giving and demanding of reasons for conduct in which people are required to explain and take responsibility for their actions" (Parker and Gould, 1999, p. 116). The concept of accountability originates in agency theory, where the agent (accountor) is responsible to render account for its actions to the principal (accountee) (Barton, 2006). This relationship can be described as one of stewardship where the agent provides information to 
the principal to meet its informational needs (Gray and Jenkins, 1993). Accountability in the public sector is more complicated than in the corporate sector. It embraces a complex web of interrelationships between government and heterogeneous stakeholders (Burritt and Welch, 1997). Pallot (1992) examined the concept of public sector accountability distinguishing between individualist and communitarian mechanisms. She argues in favour of communitarian mechanisms that bring ethical considerations into consideration and place greater emphasis upon shared values, common concerns and trust among stakeholders than upon traditional individualist values (Pallot, 1992). Such considerations are particularly relevant to environmental accountability. Indeed, as Burritt and Welch (1997) pointed out, greater prominence should be given to communitarian mechanisms when the criticality of environmental issues increases, such as in the case of biodiversity conservation.

To achieve biodiversity conservation, stakeholders need to consider the impact of their daily activities on biodiversity, so that they will avoid practices that impair biodiversity and promote those that enhance biodiversity (Convention on Biological Diversity, 2010). The adoption of such behaviours is hindered by a general lack of awareness of biodiversity's importance (Convention on Biological Diversity, 2010). Accounting can play a key role in this, as it can be used to educate organisations' stakeholders about events and fact which are unknown to them (Thomson and Bebbington, 2005). Under a communitarian approach, environmental accounting and reporting can be used to facilitate communication, creating possibilities for change (Lehman, 1999). However, communicating effectively about biodiversity's importance is challenging. To adopt effective communication strategies, organisations need to carefully evaluate the audience and what needs to be communicated. The potential stakeholders that public organisations need to make aware of the importance of biodiversity are diverse. Stakeholder theory defines stakeholders as "any group or individual who can affect or is affected by the achievement of the organisation's objective" (Freeman, 1984, p. 46). Stakeholders can be described as 'claimants', when they have some sort of claims over organisations' activities, and 'influencers', when have the capacity to influence organisations' activities, or both (Mitchell et al., 1997). In relation to biodiversity issues, the main stakeholders include residents, landowners, visitors, commerce and industry, government departments, non-governmental organisations, volunteers, community-based groups, future generations of human beings and the environment itself (Berrisford, 2010; Jones, 2003; Schneider et al., 2014). All these stakeholders are 'claimants' in that they have a legitimate claim over activities that can affect biodiversity (Eckersley, 1992). However, only 
the present generation of human beings can be considered influential, as it includes the only stakeholders with the ability to contribute to biodiversity conservation. These stakeholders are the targets of communication strategies. They are diverse and likely to have differing and competing interests and moral values, which lead them to attribute a different importance to biodiversity (Berrisford, 2010; Mueller and Maes, 2015). Local councils would therefore need to carefully consider these different values in their communication strategies.

\subsection{Biodiversity value and environmental ethics}

Different reasons for biodiversity conservation have been identified by the extant literature. Two broad groups of environmental philosophies, anthropocentric and non-anthropocentric, can be used to explain biodiversity's importance: instrumental and non-instrumental values. Biodiversity's instrumental value relies on the extent that it is useful for human ends (Justus et al., 2009). It depends on human beings' preferences. Different aspects of biodiversity can be of value for human beings for different reasons. Human beings can value biodiversity for its economic benefits, for its contribution in supporting life on Earth, for the pleasure, spiritual or aesthetic satisfaction they get from it, and so on. The mainstream environmental ethics literature has identified twelve different sources of value that can be assigned to biodiversity on the basis of its utility to human beings (see Harmon and Putney, 2003; Koziell, 2001; Rolston III, 1985, 1988; Soulé, 1985). Panel A of Table 1 illustrates these 12 sources of instrumental value.

\section{INSERT TABLE 1}

By contrast, biodiversity's non-instrumental value is based on the argument that human beings are not the only source of value. The non-human world and biodiversity are valuable for their own sake (Naess, 1973). Biodiversity's non-instrumental value is independent of any use that biodiversity might have for human beings. Biodiversity is thus good for its intrinsic value, regardless of what human beings think about it (Rolston III, 1985, 1988). The attribution of intrinsic values can reach different extents. Intrinsic value has different forms. At its most extreme all the non-human world, and thus biodiversity, has intrinsic value (Naess, 1973). Another view is that only some elements of the non-human world, such as animals or living things, have intrinsic value (Regan, 1983; Singer 1976; Sylvan, 1985). Biodiversity could be valued for its own sake or for the utility that it provides in supporting 
some of the elements of the non-human world to which intrinsic value has been assigned. Panel B of Table 1 illustrates these two sources of biodiversity non-instrumental value.

These differences are reflected in Naess's (1973) classification of shallow and deep ecology. Deep ecology philosophers attribute intrinsic value to all non-human things (Naess, 1973). Biodiversity is respected simply because it exists. By contrast, shallow ecologists assign intrinsic value only to human being and value biodiversity only in terms of human needs and ends. Anthropocentric and ecocentric philosophies represent the opposing ends of a natural spectrum. Between these two ends there are many intermediate (or weak anthropocentric) perspectives, which believe that humans being are not the only locus of value but certain nonhuman entities have intrinsic value. However, human interests always prevail (Sylvan, 1985).

The paradigms considered in this paper draw on the major streams of environmental paradigms identified by Eckersley (1992) and Connelly and Smith (2003). We considered these to be more comprehensive and relevant than other possible environmental paradigms

that we could have used $\left[{ }^{1}\right]$. They are categorised, following Sylvan (1985) and Vincent (1993), into strong anthropocentrism (shallow ecology), weak anthropocentrism (intermediate ecology) and ecocentrism (deep ecology).

\section{Shallow ecology}

Shallow ecology philosophies are based on the 'sole value assumption' according to which human beings are the only locus of intrinsic value (Sylvan and Bennet, 1994). They are concerned about biodiversity protection only because it is instrumental to the satisfaction of human beings' interests. Eckersley (1992, p. 34) identified, on a spectrum of decreasing anthropocentrism, resource conservation, human welfare ecology and preservationism as the main shallow philosophies.

\section{i) Resource Conservation}

Resource conservation is an anthropocentric paradigm that seeks a sensible and economical use of natural resources. It aims at maximising the human value by reducing inefficiencies in the consumption of non-renewable resources and maximising the sustainable yield of renewable resources (Dickerson et al., 2009). It considers the natural environment as a source of resources for the satisfaction of actual and/or potential human material needs. Resource conservation is mainly concerned with the satisfaction of material human needs, economic 
growth and the need to avoid the waste and depletion of natural resources as they are factors of production (Eckersley, 1992). It neglects non-material needs such as health, recreational, spiritual, cultural and psychological needs (Callicott, 1990). This paradigm can be used to explain biodiversity conservation strategies that justify biodiversity's importance in terms of its support to economic growth (i.e. economic value) and to the production of resources essential to humans' survival (i.e. subsistence value)

\section{ii) Human Welfare Ecology}

This anthropocentric paradigm places human beings at the centre of the natural environment conservation aiming to ensure 'environmental quality' to human beings (Eckersley, 1992, Wells, 1993). The major concern of human welfare ecology is the development of a healthy, safe, and pleasant environment. It draws attention to non-material benefits that human beings can obtain from biodiversity conservation that were neglected by the resource conservation paradigm (Eckersley, 1992). This paradigm is reflected in narratives that explain biodiversity's importance in terms of its instrumental value in creating a healthier and more agreeable environment. The instrumental values within this function are expressed in terms of life supporting, recreational and therapeutic values (Rolston III, 1985, 1988).

\section{iii) Preservationism}

This anthropocentric paradigm focuses on the preservation of aesthetically appealing places that provide opportunities for spiritual appreciation of wilderness (Callicott, 1990). It is less anthropocentric than resource conservation and human welfare ecology, as it gives nonhuman things the right to exist. However, this right is not based on the recognition of an intrinsic value, but on the fact that human beings value biodiversity through aesthetic delights, spiritual renewal and the possible scientific development (Eckersley, 1992; Corbett, 2006). This paradigm focuses mainly on the preservation of aesthetically appealing places in accord with human culture which provides human beings with a source of inspiration, irrespective of the nature of their inherent ecological content (Eckersley, 1992). Preservationism is therefore at the foundation of narratives that explain biodiversity's importance in terms of its aesthetic, scientific, spiritual, cultural-symbolization and historical values (Rolston III, 1985, 1988).

\section{Intermediate ecology}


Intermediate philosophies argue that intrinsic values should be extended to some non-human entities. However, the 'greater value assumption' dominates in which human interests always prevail in case of conflict with non-human interests (Sylvan and Bennett, 1994). The paradigms that belong to this group mainly differ in terms of the non-human entities to whom intrinsic value is attributed (sentient beings, individual living things, species etc.) and the reasons that justify the extension of intrinsic value to these non-human entities (Carter, 2007). Intermediate philosophies include: i) environmental stewardship and ii) moral extensionism (Connelly and Smith, 2003; Vincent, 1993).

\section{i) Environmental stewardship}

Human beings have a moral duty to maintain, enhance if possible, but certainly not deplete the world's natural resources. They should act as stewards of the natural environment (Jones, 2003). This concept is wide as it embraces both current and future generations of human beings. At its core is the principle that the current generation should pass onto the next generation natural resources at least equivalent to those which were inherited: human beings are trustees of God's creation. They do not own the planet; they hold it on trust. Therefore, they do not have the right to exploit the natural environment at the expense of future generations. The principles of stewardship include a responsibility for the whole Earth and intrinsic value is ascribed to the wholeness of creation. However, human beings' interests are still dominant. Environmental stewardship can, therefore, be considered as an example of weak anthropocentrism (Connelly and Smith, 2003). Narratives about the future importance of biodiversity are covered by this paradigm.

\section{ii) Moral extensionism}

Moral extensionism includes ethical approaches which extend intrinsic value to non-human entities on the basis of the possession of some critical properties. Animal liberation is an example of moral extensionism. It argues that intrinsic value should be attributed to all sentient beings because of their capacity to reason and suffer (Regan, 1983; Singer 1976). Attfield (1983) argued that sentience is a sufficient but not a necessary condition for holding intrinsic value. Plants also have value on their own. They have the capacity to flourish that gives them moral standing (Attfield, 1983, p. 154). In both cases, greater value is assigned to humans as, in cases of conflict with animals or plants' interests, human interests prevail. Explanations that justify biodiversity's importance because it supports animals or plants instrumental value to live are in line with the assumption of moral extensionism. 


\section{Ecocentrism}

Ecocentrism is based on a holistic view in which anthropocentrism is rejected. According to this paradigm "the world is an intrinsically dynamic, interconnected web of relations in which there are no absolutely discrete entities, and no absolute dividing lines between the living and the non-living" (Eckersley, 1992). Ecocentrism provided the intellectual basis for Naess's (1973) deep ecology. Under ecocentrism, both the 'sole value assumption' (i.e. only human beings have intrinsic value) and the 'greater value assumption' (i.e. human interest will prevail) are rejected. Ecocentrism argues that both human and non-human entities have intrinsic values and that it is impossible to prioritise any particular species or any element of nature (Naess, 1973). It is concerned to protect species, habitats and ecosystems irrespective of their value to humans. Biodiversity is valuable simply because it exists. Ecocentrism thus justifies biodiversity's importance in terms of its intrinsic value.

The theoretical framework used to analyse the narratives on the importance of biodiversity that combines the main environmental paradigms and biodiversity values is summarised in figure 1 .

\section{INSERT FIGURE 1}

\section{Research context: UK approach to Biodiversity conservation}

Among with many others countries, the UK is committed to halting biodiversity loss by 2020 as part of the Convention on Biological Diversity Strategy (Convention on Biological Diversity, 2010). The mechanisms through which biodiversity is protected are complex and achieved using a hierarchical framework of commitments transposed into national and local legislation. At the national level, the most important piece of legislation for biodiversity conservation is represented by the UK Biodiversity Action Plan (BAP). The UK BAP, reviews the UK biodiversity resources, analyses the principal issues that affect biodiversity conservation and proposes a forward programme for action (UK Biodiversity Action Plan Steering Group, 1994) $\left[{ }^{2}\right]$. To implement the UK BAP, the UK Government established the UK Biodiversity Steering Group, which in 1995 published two reports (UK Biodiversity Steering Group, 1995a and 1995b) that established the framework and criteria for identifying the species and the habitat types of conservation concern. It also encouraged the development of Local Biodiversity Action Plans (LBAPs) as a means of ensuring that national targets are 
translated into effective action at the local level (UK Biodiversity Steering Group, 1995a, p. 6). The development of LBAPs was also encouraged with the aim of raising awareness of the importance of biodiversity conservation in the local context (UK Local Issues Advisory Group, 1997).

LBAPs are non-statutory plans (UK Local Issues Advisory Group, 1997) whose development is voluntarily. They are considered as a means for local authorities to discharge the 'biodiversity duty' $\left[{ }^{3}\right]$ which they are subjected to, in accordance to the Natural Environment and Rural Communities Act (2006). LBAPs are typically produced via local partnerships whose main role is to identify local priorities and determine the contributions that they can make to achieve the national targets. Local partnerships are made up of public bodies, key nature conservation organisations and local communities, with local authorities playing a key role in their development and delivery (Department for Environment, Food \& Rural Affairs, 2007). Often the area covered in the LBAPs conforms to local authority boundaries. However, sometimes local authorities may decide to combine their areas and produce one integrated LBAP. To assist local authorities in the development of LBAPs a series of guidance notes have been developed (UK Local Issues Advisory Group, 1997). These notes advise on the development of the partnership, the identification of local priorities, the setting up of targets for habitat and species and on how best to relate the LBAPs with other local plans and strategies. No guidance has been provided in relationship to the length of the timehorizon to be covered by the action plan or about how often the LBAPs should be revised and updated.

\section{Research Methods}

\subsection{Data analysis}

This study uses content analysis to investigate the themes mentioned by local councils to explain the importance of biodiversity in their LBAPs. Content analysis has been extensively used in social and environmental reporting (e.g., Deegan and Rankin, 1996; Gray et al., 1995). It involves codifying the content of a piece of writing into various categories depending on selected criteria (Weber, 1990). Our categories of biodiversity value were predefined and based on the categories identified through a literature review of the studies on environmental ethics that analysed the potential arguments for the conservation of biodiversity and the natural environmental (Callicott, 1994; Harmon and Putney, 2003; 
Koziell, 2001; Rolston III, 1985, 1988; Soulé 1985). As a result, we identified 14 categories of biodiversity values, illustrated in Table 1 .

To code the LBAPs' narratives into these categories sentences were used as unit of analysis. Sentences are considered more reliable than any other unit of analysis and have been widely used as the basis for coding decisions in most social and environmental content analyses (Milne and Adler, 1999). The amount of disclosure was also measured by counting the number of sentences, as Milne and Adler (1999, p. 243) outlined that using sentences for both coding and measurement provides 'complete, reliable and meaningful data for further analysis'. However, measuring the amount of disclosure using sentences might be problematic when multiple biodiversity values are mentioned in the same sentence (Gao et al., 2005). To avoid this problem, we followed Thomas (2006) and allocated the sentence into all the categories mentioned $\left[{ }^{4}\right]$.

For each category of biodiversity value, a coding scheme was developed and validated before the beginning of the data analysis process. A list of classifying rules defining the classification criteria for each category was prepared and discussed between the researchers (Bozzolan et al., 2003). To test for the clarity and consistency of our categories and provide validation of the coding scheme, five LBAPs were initially analysed and independently coded by two researchers. The results of the individual classifications were then compared by the two researchers and misalignments identified. Any discrepancy was re-analysed and resolved by discussion between the two researchers (e.g., Lee, 1999). Following this procedure, a final set of coding rules was defined. Once the coding scheme was finalised, the narrative sections of the remaining LBAPs were read in their entirety to identify disclosures related to the value of biodiversity, the importance of preserving biodiversity and/or adopting biodiversity strategies or action plans. These narratives were then recorded on a coding spread sheet and allocated first into the 14 categories of biodiversity value illustrated in table 1 and then into the six environmental paradigms.

\subsection{Sample}

To investigate our research questions, we analysed the biodiversity action plans and biodiversity strategy (hereafter we use the term LBAPs to refer to both documents) published by UK local councils. We decided to focus on the UK institutional setting as the UK was the first country to produce, in 1994, a national biodiversity action plan which encouraged local councils to develop local plans to conserve biodiversity. We focused on these plans to 
investigate the disclosure of biodiversity's importance as one of the main functions of these documents is to raise awareness of the need for biodiversity conservation in the local context (UK Local Issues Advisory Group, 1997). We searched the website of 206 local councils, and found 143 LBAPs prepared by 149 local councils from 1998 to $2015\left[^{5}\right]$. One hundred and twenty-three of these LBAPs covered an area managed by one local council, while the remaining 20 covered the area managed by two or more local councils $\left[{ }^{6}\right]$. Most local councils analysed (112) prepared only one LBAP. The remaining 37 local councils subsequently published updated and revised versions of their LBAPs: 29 of them prepared two LBAPs and eight three LBAPs.

\section{Results}

\subsection{Levels of LBAP disclosures}

Table 2 reports the descriptive statistics of the UK LBAPs analysed.

\section{INSERT TABLE 2}

On average LBAPs had 77 pages, contained 1,454 sentences and 23,090 words. The need to raise awareness of biodiversity's importance was indicated as one of the main objectives pursued by the plan in more than $90 \%$ of the cases. The importance of biodiversity was discussed in more than $81 \%$ of LBAPs analysed with an average of 12 sentences and 240 words. Biodiversity's importance received greater emphasis in $52 \%$ of the LBAPs, where it was discussed in a specific sub-section of the action plan.

Table 2 provides a breakdown of the LBAPs into the different years of publication. It shows that the year in which by far the most LBAPs were developed was 2010 (22 out of 143). Interestingly, after 2010 there was a large increase in the number of disclosures of biodiversity's importance. The average number of sentences on biodiversity's importance increased from nine in 1998-2009 to sixteen in 2010-2015. These results can be explained by considering that 2010 was declared by the United Nations as the International Year of Biodiversity with the aim of celebrating the value of biodiversity and its importance to life on Earth and of raising political and public awareness of the importance of biodiversity worldwide. Local councils appear to have been influenced by the global attention to biodiversity and this seems to have prevailed over national influences. This seems to have encouraged local councils not only to develop and publish biodiversity strategies, but also to 
use the LBAPs as communication tools to bring attention to the importance of biodiversity conservation.

\subsection{Biodiversity values used to explain biodiversity's importance}

Table 3 provides an overview of the categories of biodiversity values used by UK local councils to explain the importance of biodiversity conservation to their stakeholders.

\section{INSERT TABLE 3}

As Table 3 shows, most of these narratives discussed the role played by biodiversity in providing services which support the life on Earth. Biodiversity life supporting value was mentioned in $59 \%$ of the documents analysed and had the highest number of sentences (on average 4.9 sentences were used). The life supporting value of biodiversity was mostly used to illustrate the material benefits that human being obtain from ecosystem regulating services (e.g. water purification, flood and disease control and pollination) and supporting services (e.g. soil formation and nutrient cycling) (Millennium Ecosystem Assessment, 2005). Economic, recreational and therapeutic values were the other most popular values used to explain biodiversity's importance, being mentioned in respectively $57 \%, 45 \%$ and $41 \%$ of the LBAPs analysed. Economic and therapeutic values were not only frequently mentioned, but also extensively discussed. By contrast, recreational values were discussed with the use of relatively short narratives.

When biodiversity values were discussed, local councils made extensive references to specific stakeholders. Life supporting, therapeutic and recreational values were often associated with stakeholders such as residents, visitors and citizens. For example, the Camden BAP (Camden Council, 2013, p. 3) stated that:

The amount of green space in a neighbourhood has been found to increase the sense of wellbeing among residents; biodiverse green spaces can further increase this feeling among visitors.

Narratives about biodiversity economic value were instead mostly associated with stakeholders such as businesses, industry, workers, farmers and land-managers. For instance, the East Riding of Yorkshire BAP (East Riding of Yorkshire Council, 2010, p. 3) highlighted the support of biodiversity to our economy in terms of "new market opportunities for farmers 
and land managers through farm diversification". Other current stakeholders, such as nongovernmental organisations, conservation groups and environmentalist were barely mentioned in relationship to any biodiversity value.

Biodiversity's future and intrinsic values were also mentioned the most. Biodiversity future value was acknowledged in 36\% of the LBAPs analysed with an average length of 1.9 sentences. The narratives that illustrated the future value of biodiversity stressed the interests of future generations in inheriting natural resources at least equivalent to those inherited by the previous generations. Biodiversity intrinsic value was acknowledged in $34 \%$ of the LBAPs analysed, but with relatively short narratives (on average only 1.9 sentences were used). Most of these LBAPs made a short reference to the intrinsic value of biodiversity without providing many details. Other biodiversity instrumental values, scientific and historical values, in particular, and the instrumental benefits that biodiversity provide to nonhuman living things were less frequently mentioned and with relatively short narratives.

Two new categories of biodiversity value emerged during the categorisation process, as some of the narratives used to explain biodiversity's importance could not be classified into any of the pre-existing 14 categories of biodiversity values (see Table 3). The first category, we named 'legal value', was found in $13 \%$ of the LBAPs analysed. It includes narratives that explained the importance of biodiversity conservation as necessary to comply with legislative requirements. For example the Harrow BAP (Harrow Council, 2015, p. 2) states that the conservation of biodiversity is important "to meet legal commitments under the Natural Environment and Rural Communities Act 2006". The second category, we named 'general anthropocentric value', includes narratives used to explain biodiversity's importance in general anthropological terms, without making an explicit reference to specific human beings' needs. The statement "it is often taken for granted but the natural world plays an important part in our everyday lives", found in the Northamptonshire BAP (Northamptonshire Biodiversity Partnership, 2008, p. 3), provides an example of narratives classified within this category. Such narratives were found in $39 \%$ of the LBAPs analysed.

Figure 2 depicts the temporal changes to the overall disclosure of biodiversity's importance and to the disclosure of the three macro-categories of biodiversity values (instrumental value to human beings, instrumental value to life and intrinsic value) over the period covered by this study. 


\section{INSERT FIGURE 2}

It shows that during the period analysed the level of narratives used to explain biodiversity's importance were subjected to relevant fluctuations. After initially decreasing from 16 sentences in 2004 to four in 2009, the number of disclosures on biodiversity's importance more than quadrupled in 2010, reaching a peak of 23 in 2013. We believe that the increase occurred in 2010 is associated with the greater pressure to raise awareness on biodiversity and the greater global attention that was given to biodiversity during this year. This appears to have led local councils to disclose more information on biodiversity's importance in their LBAPs. However, we find it quite surprising that, as shown by Figure 2, the increase in the level of disclosure of biodiversity's importance in 2010 is not due to an increase in intrinsic value. Instead, it is explained by an increase in instrumental value. We would have expected that the increase in the global attention would have increased the acknowledgement of biodiversity's intrinsic value, as this value is a central tenet of the Convention on Biological Diversity. By contrast, the level of narratives on biodiversity's intrinsic value remained both stable and low.

\subsection{Analysis of the disclosures of biodiversity's importance in terms of shallow, intermediate} and deep philosophies

Table 4 reports the classification of the arguments used by UK local councils to explain the importance of biodiversity within the six environmental paradigms considered in this study: resource conservation, human welfare ecology, preservationism, environmental stewardship, moral extensionism and ecocentrism. It shows that most of the narratives on the importance of biodiversity conservation were in line with shallow philosophies, in particular resource conservation and human welfare ecology, rather than with intermediate or ecocentric philosophies. Our findings show that $86 \%$ of the narratives on biodiversity's importance were focussed on the illustration of benefits that biodiversity provides to human beings.

\section{INSERT TABLE 4}

Narratives based on human welfare ecology were the most recurrent representing $43 \%$ of the narratives analysed. The theoretical underpinnings of this paradigm, which argues in favour of environmental policies focussed on the value of the environment for human health and happiness (Eckersley, 1992) and believes that 'environmental quality' is something that is 
owed to all people (Wenz, 1988), have been widely recognised in the LBAPs analysed. The Somerset Biodiversity Strategy (Somerset Biodiversity Partnership, 2008, p. 8) explains that:

Having access to natural green space is an important component of our quality of life, improving mental and physical wellbeing and helping to tackle serious modern day problems such as stress, obesity and social isolation.

Similarly, the Camden BAP (Camden Council, 2013, p. 6) states:

There is not equal access to the natural environment across Camden and this plan will seek to address those inequalities so that all of our residents have the opportunity to access the benefits that biodiversity can provide.

After human welfare ecology, the next most frequently occurring narratives on biodiversity's importance were on resource conservation. Around $21 \%$ of the disclosures on biodiversity's importance stressed the role played by biodiversity in providing the natural resources necessary for the satisfaction of fundamental human needs, supporting the development of local industries and economic growth. References to this paradigm were found in several documents, such as the Saint Helens BAP (Saint Helens Council, 2006, p. 19), which acknowledged that by protecting biodiversity "the Borough can present a positive image of itself, helping to attract new residents and stimulate economic growth". Resource conservationism has been historically concerned with environmental issues such as flood control, soil reclamation and oil maximisation (Dickerson et al., 2009). These issues have been widely discussed, as in the case of the Lincolnshire BAP (Lincolnshire Biodiversity Partnership, 2011, pp. 3-4), to explain the economic benefits generated by the adoption of its biodiversity strategies.

Among the shallow anthropocentric philosophies, preservationism is the paradigm that was mentioned the least. Less than $10 \%$ of the narratives discussed the importance of biodiversity in terms of its aesthetical, spiritual, scientific, cultural-symbolisations and historical value. The following extract from the Lowland Derbyshire BAP (Lowland Derbyshire Biodiversity Partnership, 2011, p. 3) incorporates the spirit of preservationism: 
The ability to experience nature - walking in an ancient broadleaf woodland, watching butterflies in a meadow on a summer's day, or simply watching the birds in our garden or outside our office window - all of these experiences enrich our lives on a daily basis, and often provide a sense of wellbeing.

Intermediate paradigms were reflected in $9 \%$ of the narratives analysed. Most of these narratives reflect the assumption of environmental stewardship. The terms "stewardship" or "steward" were never mentioned. However, some LBAPs acknowledged the moral duty to conserve biodiversity for the sake of future generations, as in the (Lowland Derbyshire Biodiversity Partnership, 2011, p. 5) which pointed out that:

We have a moral duty to ensure that we pass on a healthy, functioning natural environment to future generations, so that they might equally have the opportunity to experience it, and benefit from it themselves. Indeed, the idea that we should ensure we pass on an environment capable of meeting the needs of future generations is a key principle of sustainable development.

Narratives on biodiversity's importance reflecting moral extensionism occurred less frequently. Only $3 \%$ of the narratives analysed discussed the value of biodiversity for nonhuman living things. An example was found in the Waltham Forest BAP (Waltham Forest Council, 2011, p. 2), which stated that biodiversity is important as "species which have evolved very slowly may be lost very quickly and cannot be replaced".

Ecocentric paradigms were seldom reflected in the disclosures on biodiversity's importance. Only $5 \%$ of the disclosures on biodiversity's importance had an ecocentric focus. Ecocentric paradigms are based on a holistic view of the world according to which "the world is an intrinsically dynamic, interconnected web of relations in which there are no absolutely discrete entities, and no absolute dividing lines between the living and the non-living" (Eckersley, 1992). These principles are reflected in the Fife BAP (Fife Council, 2013, p. 5) which explained biodiversity's importance by stating that:

Biodiversity has intrinsic value - it is valuable in its own right. Over 1.75 million species have been identified on earth, but scientists estimate there could be as many as 14 million! In Scotland, we have around 90,000 species. The biodiversity we see today is the fruit of billions of years of evolution. Indeed, most of it has been around far longer than we have. This natural wonder is worth protecting in itself. 
Another example of narratives inspired by ecocentrism is provided by the Lincolnshire BAP that stated that "humans are simply part of nature, not dominating it, thus we should seek to conserve the value in the rest of nature" (Lincolnshire Biodiversity Partnership, 2011, p. 4). This statement was then reinforced with a quotation from Aldo Leopold:

A land ethic changes the role of Homo sapiens from conqueror of the land-community to plain member and citizen of it. It implies respect for his fellow-members, and also respect for the community as such.

\section{Discussion}

Sustainability and environmental accounting have been criticised for acting as a legitimising tool, rather than as an accountability tool leading to the adoption of sustainable behaviours (Gray, 2010). A communitarian approach that envisages interchange between all levels in a community has been suggested as a way forward to overcome flaws identified in the current sustainability practices (Gray, 2010; Lehman, 1999). Several studies have argued that a communitarian approach to environmental accountability should be developed, particularly in the public sector, by providing information to the community about environmental impacts in order to create avenues for discussion on the relationship between humanity and nature (Burritt and Welch, 1997; Lehman, 1999; Pallot, 1992). LBAPs are examples of communitarian accountability tools based on a communication approach aimed at raising awareness of biodiversity's importance. These plans provide stakeholders with information about the impact that biodiversity losses will have on humanity and the natural world. This has the potential to stimulate discussions about the impact of human activities on biodiversity and lead to positive changes on stakeholders' approach to biodiversity (Lehman, 2002).

When the six environmental paradigms considered in our theoretical framework are analysed using stakeholder theory, we can recognise that each paradigm puts the interests of different stakeholders at the core of its philosophy. All the anthropocentric paradigms put the present generation of human beings, who are influential stakeholders, at the centre of their philosophies (Callicott, 1994; Eckersley, 1992), but attribute different prominence to diverse categories of human beings. As shown in our findings, the arguments used for resource conservation mainly address the interest of stakeholders, such as commerce and industry, landowners, farmer and workers, who are more concerned about the role played by 
biodiversity in supporting industrial and commercial activities and favour economic development. Human welfare ecology, which is concerned with the development of a healthy, safe, and pleasant environment, addresses more the interest of stakeholders as residents, citizens and visitors. Preservationists use arguments that are more in line with the interest of those stakeholders, such as volunteer and conservation organisations, who acknowledge the importance of biodiversity for its intangible values. By contrast, the arguments for biodiversity conservation raised by weak anthropocentric and ecocentric philosophies are more in line with the interests of those stakeholders that have some claims over the activities that affect biodiversity, but have no ability to influence them. At the core of environmental stewardship there are the interests of future generations of human beings (Jones, 2003). Moral extensions advocate biodiversity conservation for the sake of other living things, such as animals and plants (Attfield 1983). Ecocentric philosophies based their arguments on the need to conserve biodiversity for its own sake (Naess, 1973). These categories of stakeholders are not able to play any role in biodiversity conservation.

Biodiversity reporting initiatives aimed at raising awareness of biodiversity's importance have the ultimate goal of encouraging stakeholders to consider the impact that their daily activities can have on biodiversity. Argumentations based on anthropocentric philosophies are likely to be more effective in this sense (van Liempd and Busch, 2013; Wells 1993). This explains why the narratives used by UK local councils to explain biodiversity's importance were more in line with these philosophies. The decreased prominence given to preservationism is due to the fact that the stakeholders whose interest are reflected in this philosophy (e.g. environmentalist and conservation groups) are already aware of biodiversity's importance and for this reason are likely to already be taking biodiversity consideration into account. Stakeholders as residents, industry, commerce, workers and landowners are likely to be those that need to be convinced the most about the importance of biodiversity, as they are more likely to ignore biodiversity's importance and perform activities that generate biodiversity losses (van Liempd and Busch, 2013; Wells, 1993). This explains why argumentations based on the philosophical foundations of human welfare ecology and resource conservation have been found to be more recurrent. The predominance of human welfare ecology is in line with the thinking of Wells (1993), who argued that stressing the deleterious consequences that the destruction of the natural world would have for human survival, health and happiness is the most forceful argument that can be made for biodiversity and environmental conservation. 
Our findings show that like private sector organisations, organisations in the public sector perpetuate the use of an instrumental approach to nature in their environmental accounting and reporting practices. We have argued that this approach provides stronger arguments to promote environmental conservation. However, this instrumental thinking has the potential to hinder the development of ethical and moral standards in society (Lehman, 2017). As accounting can also educate organisations' stakeholders (Thomson and Bebbington, 2005), a focus on more intangible values, such as aesthetical and spiritual values, and intrinsic value is necessary to encourage moral behaviour and inspire citizens to consider better ways to live (Lehman, 2017). In this sense, a communication approach that explains the importance of biodiversity following multiple ethical positions and encourages engagement between these different perspectives would help to diffuse a broader vision and understanding of biodiversity's meaning in our society (Byrch et al., 2015; Lehman, 2017).

\section{Conclusions}

This study sheds light on the use of biodiversity reporting as a communication tool to raise public awareness on the importance of biodiversity, by analysing 143 LBAPs published by UK local councils during the period 1998-2015. To evaluate whether local councils used LBAPs to promote awareness of biodiversity's importance among their stakeholders we first analysed the aims and objectives of the LBAPs and then the presence of narratives that explained biodiversity's importance. We found that most of LBAPs analysed were used to diffuse a general understanding of biodiversity's importance. By using content analysis, the narratives on biodiversity's importance were analysed first to identify the main categories of biodiversity values used to explain biodiversity's importance and then to evaluate their consistency with the theoretical constructs of shallow (resource conservation, human welfare ecology and preservationism), intermediate (environmental stewardship and moral extensionism) or deep philosophies. Stakeholder theory was used to explain the philosophical foundations of these narratives.

Our findings show that local councils adopted a pragmatic approach in explaining the importance of biodiversity. The majority of the narratives on biodiversity's importance have a focus consistent with anthropocentric paradigms, such as human welfare ecology and resource conservation. Preservationism, weak anthropocentric philosophies, such as environmental stewardship and moral extensionism, and ecocentric philosophies, although 
embraced in several documents were less recurrent. These findings confirm the fundamental assumptions of stakeholder theory in relation to the processes by which organisations relate to their stakeholders (Freeman 1984; Mitchell et al., 1997). In line with stakeholder theory, our study indicates that local councils explain biodiversity's importance using arguments that are likely to be more effective to convince those stakeholders whose behavioural needs to be changed to stop (or limit) biodiversity loss. These include stakeholders, such as business, industry, residents, visitors, workers, farmer and landowners, who have the ability to provide a contribution towards biodiversity conservation (Mitchell et al., 1997), but are more sceptical about biodiversity's importance (van Liempd and Busch, 2013; Wells 1993).

This study provides significant contributions to the accounting literature in six different ways. First, by focussing on biodiversity reporting, this study extends the accounting literature on environmental reporting. Indeed, with a few exceptions (Atkins et al., 2014; Barut et al., 2016; Boiral, 2016; Rimmel and Jonäll, 2013; Samkin et al., 2014; Schneider et al., 2014; van Liempd and Busch, 2013) biodiversity reporting has been largely ignored by accounting studies. Most of the studies on biodiversity reporting have analysed companies. Our study is, to our knowledge, one of the first, after Schneider et al. (2014) and Barut et al. (2016), to investigate biodiversity reporting by local authorities. In contrast to Schneider et al. (2014) and Barut et al. (2016) who investigated biodiversity reporting as a means of enabling stakeholders to assess local authority performance of biodiversity conservation, our study has analysed biodiversity reporting as a tool aimed at increasing stakeholders' awareness of biodiversity related issues. Moreover, while the prior studies have investigated biodiversity reporting of public authorities operating in New Zealand and Australia, our study focussed for the first time on local authorities operating in a European country.

Second, it expands the limited number of studies within the accounting literature that have engaged with environmental ethics (e.g. Andrew, 2000; Buhr and Reiter, 2006; Gray, 1992; Hines, 1991; Lehman, 2017; Samkin et al. 2014). It therefore answers the call of Andrew (2000) for the development of more environmental accounting research informed by different environmental ethical positions. Within this limited accounting literature, our study builds on the previous works of Buhr and Reiter (2006) and Samkin et al. (2014). Buhr and Reiter (2006) showed that environmental reporting primarily reflected the arguments of anthropocentric rather than ecocentric philosophies. Samkin et al. (2014) analysed the narratives on biodiversity included in the annual reports published by a New Zealand 
conservation organisation in terms of shallow, intermediate and deep ecology. In contrast with our study, they found that biodiversity-related narratives mainly reflected a deep ecological philosophy. This difference is probably related to the different biodiversity-related narratives analysed by the two studies. Our study examined narratives on the importance of biodiversity, while Samkin et al (2014), focused on narratives on specific biodiversity conservation projects and the performance achieved.

Third, this study contributes to one of the major debates in environmental ethics about whether we should develop and promote a non-anthropocentric attitude as a primary means to solve the environmental crisis (e.g. Callicott, 1994; Eckersley, 1992; Lehman, 2017; Norton, 1994). Biodiversity conservation politics based on anthropocentric environmental philosophies have been harshly criticised by supporters of ecocentric orientation for being inadequate and possibly counterproductive in pursuing biodiversity conservation (Eckersley, 1992). Our study does not wholly support this view. Anthropocentric arguments that appeal more directly to stakeholders' resource conservation and human welfare interests are likely to reach and positively impact a wider audience, thus encouraging biodiversity conservation (Milne, 1996; Norton, 1994; van Liempd and Busch, 2013; Wells, 1993). Our study supports Norton (1994) that the strongest argument to be used to constrain human beings' behaviour towards biodiversity conservation is based on its importance for human beings survival. However, it also argues that the use of arguments based on both instrumental and intrinsic values is necessary to promote the development of ethical and moral standards in society (Byrch et al., 2015; Lehman, 2017).

Fourth, this study is innovative as it gives us some insight into how global developments might affect local governments. We found much to our surprise that the 2010 biodiversity year had a great effect on municipal disclosures. This seemed to reflect the wider global publicity. However, this increased disclosure focused on anthropocentric values and not intrinsic values. By encouraging such anthropocentric views, it may be that councils hope to educate stakeholders. This would result in an increase in overall respect and attention to biodiversity. This may prove an interesting area of future research.

Fifth, our study contributes to the environmental ethics literature in environmental values.

On top of the 14 values shown in Table 3, we found that two new values were used by local governments. The most important of these was legal value where narratives were used to 
explain the importance of biodiversity to comply with legislative requirements. In addition, there was a general anthropocentric value where the importance of biodiversity was explained in general terms.

Last but not least, this study contributes to the literature on public sector accountability (e.g. Ball et al., 2012; Burritt and Welch, 1997; Gray and Jenkins, 1993; Pallot, 1992; Parker and Gould, 1999) by analysing the provision of biodiversity information under a communitarian approach to accountability. This considers accounting as a communicative technology that provides avenues for discussion and debate concerning social and environmental issues (Lehman, 1999; Pallot, 1992, Thomson and Bebbington, 2005). Previous studies on public sector organisations have suggested the need of accountability approaches based on communitarian rather than individualistic values (Ball and Seal, 2005; Lehman, 1999; Pallot, 1992) and the development of new mechanisms to change how people relate to the natural environment (Lehman, 2002). This study provides empirical evidence of such mechanisms by showing how UK LBAPs were used as communication tool to raise awareness on biodiversity within society with the ultimate aim of changing the behaviour of a wide range of stakeholders in relation to biodiversity issues.

As in any research, this study is subject to several limitations, which in turn offer new avenues for future research. First, we analysed biodiversity reporting in a single institutional setting. We are aware that our empirical findings might be context specific and that any generalisation out of this specific context might be difficult. Future studies might obtain a more comprehensive portrait by extending the analysis to additional countries. Second, our sample might not include all the biodiversity action plans prepared by UK local councils, as it is possible that some of them were not made accessible through the websites. However, as websites are nowadays the fastest, cheapest and most accessible way to acquire information, we believe that we have accessed the most relevant documents. Third, local councils may have used other communication tools such as media and press releases, video, images or digital communications, rather than biodiversity reports to raise awareness of biodiversity value. Future study might investigate these communications tools. Fourth, our study only provides evidence on how LBAPs were used to attempt to raise stakeholders' awareness of biodiversity's importance. It does not measure their effectiveness. This might be an interesting research area for future studies. Finally, this study has examined only the information publicly disclosed by local councils. As suggested by Ball et al. (2012), it would 
be useful to conduct further studies which directly engage with people that work in public bodies which regulate and develop biodiversity practices.

\footnotetext{
${ }^{1}$ These include: the new environmental paradigm, the dominant social paradigm, adaptive, goal-directed and sociocultural paradigms (Hawcroft \& Milfont, 2010; Saegert and Winkel, 1990; Williams and Patterson, 1996). The dominant social paradigm is based on a system of beliefs centred on unlimited economic growth, abundance of ecological resources and strong resistance to change. The new environmental paradigm, by contrast, is based on the belief that human beings should live in harmony with the environment and limit their expansions. The adaptive paradigm assumes that human beings evaluate the environment for its contribution to health and wellbeing. The goal-directed paradigm views the environment as a source of resources to satisfy human needs, while the sociocultural paradigm values natural resources because of emotional and symbolic meaning. These paradigms appear to be less comprehensive and less relevant for explaining the importance of biodiversity conservation than the philosophical approaches considered in the study, as they relate to only a few of the different categories of biodiversity values identified in the environmental literature.

${ }^{2}$ The program of action set out in the UK BAP was then revised in 2012 by the UK Post-2010 Biodiversity Framework, which sets out a plan to achieve the aims of the Convention on Biological Diversity Strategy.

${ }^{3}$ The key purpose of this duty is to raise the profile and visibility of biodiversity, clarify existing commitments regarding biodiversity and make consideration of biodiversity an integral part of policy and decision making in the public sector (Department for Environment, Food \& Rural Affairs, 2007).

${ }^{4}$ For instance, in the following sentence "By protecting our biodiversity we offer ourselves greater opportunities for future economic development, future medical discoveries and adaptive responses to threats yet to be discovered" in the Rotherham BAP (2004, p. 6) both biodiversity's economic and scientific values were mentioned. We counted disclosure by attributing one sentence to economic value and one sentence to scientific value.

${ }^{5}$ The sample includes 152 English, 32 Scottish and 22 Welsh local councils. Northern Ireland local councils were excluded as during the period analysed they were the subject of the "Reform of local government in Northern Ireland" in 2002 which led between 2014 and 2015 to the replacement of the original 26 local councils created in 1973 with 11 local councils.

${ }^{6}$ Out of these 20 LBAPs, five covered the area managed by two local councils, ten LBAPs the area of three local councils, and five LBAPs the area managed by five or more local councils.
} 


\section{References}

Andrew, J. (2000), "The accounting craft and the environmental crisis: reconsidering environmental ethics", Accounting Forum, Vol. 24 No. 2, pp. 197-222.

Atkins, J., and Atkins, B. Eds, (2016), The Business of Bees: An Integrated Approach to Bee Decline and Corporate Responsibility, Greenleaf Publishing, Saltaire, UK.

Atkins, J., Gräbsch, C., and Jones, M.J. (2014), “Corporate Biodiversity Reporting” in Jones, M.J. (Ed.), Accounting for Biodiversity, Routledge, London, pp. 215-244.

Attfield, Robin (1983), The Ethics of Environmental Concern, Blackwell, Oxford, UK.

Ball, A., and Seal, W. (2005), "Social justice in a cold climate: could social accounting make a difference?", Accounting Forum, Vol. 29 No. 4, pp. 455-473.

Ball, A., Soare, V., and Brewis, J. (2012), "Engagement research in public sector accounting", Financial Accountability \& Management, Vol. 28 No 2, pp.189-214.

Barton, A.D., (2006), "Public sector accountability and commercial-in-confidence outsourcing contracts", Accounting, Auditing \& Accountability Journal, Vol. 19 No 2, pp. 256-271.

Barut, M., Raar, J., and Azim, M.I. (2016) "Biodiversity and local government: a reporting and accountability perspective”, Managerial Auditing Journal, Vol. 31 No 2, pp. 197-227.

Berrisford, K. (2010), "Communication \& Participation in Biodiversity", in Laros M.T. and Jones F.E. (Eds), Local Action for Biodiversity Guidebook: Biodiversity Management for Local Governments, International Council for Local Environmental Initiatives, Bonn, pp. 124-143.

Boiral, O (2016), “Accounting for the Unaccountable: Biodiversity Reporting and Impression Management", in Journal of Business Ethics, Vol. 135 No. 4, pp. 751-768.

Boiral, O., and Heras-Saizarbitoria, I. (2017), "Managing Biodiversity Through Stakeholder Involvement: Why, Who, and for What Initiatives?", Journal of Business Ethics, Vol. 140 No 3 , pp 403-421.

Bozzolan, S., Favotto, F., and Ricceri, F. (2003), "Italian annual intellectual capital disclosure: an empirical analysis", Journal of Intellectual Capital, Vol. 4 No 4, pp. 543-558.

Buhr, N., and Reiter, S. (2006), "Ideology, the environment and one worldview: A discourse analysis of Noranda's environmental and sustainable development reports", Advances in environmental accounting and management, Vol. 3, pp. 1-48.

Burritt, R.L. and Welch, S. (1997), "Accountability for environmental performance of the Australian Commonwealth public sector", Accounting, Auditing \& Accountability Journal, Vol. 10 No. 4, pp. 532-550. 
Byrch, C., Milne, M.J., Morgan, R., and Kearins, K. (2015), "Seeds of hope? Exploring business actors' diverse understandings of sustainable development", Accounting, Auditing \& Accountability Journal, Vol. 28 No 5, pp. 671-705.

Callicott, J.B. (1990), “Whither conservation ethics?”, Conservation Biology, Vol. 4 No 1, pp. $15-20$.

Callicott, J.B. (1994), "Conservation Values and Ethics", in Meffe, G.K. and Carroll C.R. (Eds), Principle of Conservation Biology, Sinauer and Associates, Sunderland, MA, pp. 2942.

Camden Council (2013), Camden Biodiversity Action Plan 2013-2018, available at: https://www.camden.gov.uk/ccm/content/leisure/outdoor-camden/wildlife-and-natureconservation/biodiversity-and-nature-conservation.en?page=1\#section-3.

Carter, N. (2007), The Politics of the Environment. Ideas, Activism, Policy, 2nd Edition, Cambridge University Press, Cambridge.

Chapin III, F.S., Zavaleta, E.S., Eviner, V.T., Naylor, R.L., Vitousek, P.M., Reynolds, H.L. and Mack, M.C. (2000), “Consequences of changing biodiversity”, Nature, Vol. 405, pp. 234-242.

Connelly, J., and Smith, G. (2003), Politics and the environment: from theory to practice, Routledge, London.

Convention on Biological Diversity (2010), Strategic Plan for Biodiversity 2011-2020, Secretariat of the Convention on Biological Diversity, Montreal.

Corbett, J. B. (2006), Communicating nature: How we create and understand environmental messages, Island Press, Washington, DC.

Cuckston, T. (2013), "Bringing tropical forest biodiversity conservation into financial accounting calculation", Accounting, Auditing \& Accountability Journal, Vol. 26 No 5, pp. 688-714.

Deegan, C. (2002), "Introduction: the legitimising effect of social and environmental disclosures - a theoretical foundation", Accounting, Auditing \& Accountability Journal, Vol. 15 No. 3, pp. 282-311.

Deegan, C., and Rankin, M. (1996), "Do Australian companies report environmental news objectively? An analysis of environmental disclosures by firms prosecuted successfully by the Environmental Protection Authority", Accounting, Auditing \& Accountability Journal, Vol. 9 No 2, pp. 50-67.

Department for Environment, Food \& Rural Affairs (2007), Guidance for Local Authorities on Implementing the Biodiversity Duty, London. 
Dickerson, M. O., Flanagan, T., Dickerson, M.O., \& O'Neill, B. (2009), An Introduction to Government and Politics: A Conceptual Approach, Cengage Learning, Boston, MA.

East Riding of Yorkshire Council (2010), East Riding of Yorkshire Biodiversity Action Plan Strategy, available at: http://www2.eastriding.gov.uk/council/plans-and-policies/other-plansand-policies-information/sustainable-environment-policies-and-strategies/.

Eckersley, R. (1992), Environmentalism and political theory: Toward an ecocentric approach, UCL press, London.

Fife Council (2013), Fife Local Biodiversity Action Plan 2013-2018, available at: https://www.fifedirect.org.uk/publications/index.cfm?fuseaction=publication.pop\&pubid=5D 13F710-D8AD-B0EA-F25DCB3DAF712223.

Freeman, R.E. (1984), Strategic management: A stakeholder approach, Pitman, Boston, MA. Gao, S., Heravi S. and Xiao, J.Z. (2005), "Determinants of corporate social and environmental reporting in Hong Kong: a research note”, Accounting Forum, Vol. 29 No. 2, pp. 233-242.

Gray, R. (1992), “Accounting and Environmentalism: an Exploration of accounting needs of gendy accounting for accountability, transparency and sustainability", Accounting, Organisations and Society, Vol. 17 No 5, pp. 399-425.

Gray, R. (2010), "Is accounting for sustainability actually accounting for sustainability ....and how would we know? An exploration of narratives of organisations and the planet", Accounting, Organisations and Society, Vol. 25 No. 1, pp. 47-62.

Gray, A., and Jenkins, B. (1993), "Codes of accountability in the new public sector", Accounting, Auditing \& Accountability Journal, Vol. 6 No 3.

Gray, R., Kouhy, R., and Lavers, S. (1995), "Corporate social and environmental reporting: a review of the literature and a longitudinal study of UK disclosure", Accounting, Auditing \& Accountability Journal, Vol 8 No 2, pp. 47-77.

Harmon, D., and Putney, A. (2003), The full value of parks: from economics to the intangible, Rowman \& Littlefield Publishers, Lanham, MD.

Harrow Council (2015), Harrow Biodiversity Action Plan 2015-2020, available at: https://www.harrow.gov.uk/download/downloads/id/556/harrow_biodiversity_action_plan.

Hartig, T., Mang, M., and Evans, G.W., 1991, "Restorative effects of natural environment experience", Environment and Behavior, Vol. 23, pp. 3-26.

Hawcroft, L.J., and Milfont, T.L. (2010), “The use (and abuse) of the new environmental paradigm scale over the last 30 years: A meta-analysis", Journal of Environmental psychology, Vol. 30 No 2, pp. 143-158. 
Hines, R. (1991), "On Valuing Nature”, Accounting, Auditing and Accountability Journal, Vol. 4 No 3, pp. 27-29.

Jones, M.J. (1996), “Accounting for biodiversity: a pilot study”, The British Accounting Review, Vol. 28 No 4, pp. 281-303.

Jones, M.J. (2003), “Accounting for biodiversity: operationalising environmental accounting", Accounting, Auditing \& Accountability Journal, Vol 16 No 5, pp. 762-789.

Jones, M.J., and Solomon, J.F. (2013), "Problematising accounting for biodiversity", Accounting, Auditing \& Accountability Journal, Vol. 26 No 5, pp. 668-687.

Justus, J., Colyvan, M., Regan, H., and Maguire, L. (2009), "Buying into conservation: intrinsic versus instrumental value", Trends in Ecology \& Evolution, Vol. 24 No 4, pp. 187191.

Khan, T. (2014), "Kalimantan's biodiversity: developing accounting models to prevent its economic destruction", Accounting, Auditing \& Accountability Journal, Vol. 27 No 1, pp. 150-182.

Koziell, I. (2001), Diversity not adversity: Sustaining livelihoods with biodiversity, International Institute for Environment and Development, London.

Lee, T. (1999), Using qualitative methods in organisational research, Sage, Thousand Oaks, CA.

Lehman, G. (1999), "Disclosing new worlds: a role for social and environmental accounting and auditing", Accounting, Organisations and society, Vol. 24 No 3, pp. 217-241.

Lehman, G. (2002), "Global accountability and sustainability: research prospects", Accounting Forum, Vol. 26 No 3-4, pp. 219-232.

Lehman, G. (2017), "The language of environmental and social accounting research: The expression of beauty and truth", Critical Perspectives on Accounting, Vol. 44, pp. 30-41.

Lincolnshire Biodiversity Partnership (2011), Lincolnshire Biodiversity Action Plan 20112020, available at: https:/www.nelincs.gov.uk/wp-content/uploads/2016/02/201110LincolnshireBAP-3rd-edition.pdf.

Lowland Derbyshire Biodiversity Partnership (2011), Lowland Derbyshire Biodiversity Action Plan, available at: http://www.derbyshire.gov.uk/environment/conservation/Ecology/lowland_derbyshire_biodi versity_action_plan/

Millennium Ecosystem Assessment (2005), Ecosystems and human well-being, Island Press, Washington, DC. 
Milne, M.J. (1996), "On sustainability; the environment and management accounting", Management Accounting Research, Vol. 7 No. 1, pp. 135-161.

Milne, M.J., and Adler, R.W. (1999), "Exploring the reliability of social and environmental disclosures content analysis", Accounting, Auditing \& Accountability Journal, Vol 12 No 2, pp. 237-256.

Mitchell, R., Agle, B., and Wood, D. (1997), “Toward a Theory of Stakeholder Identification and Salience: Defining the Principle of Who and What Really Counts", The Academy of Management Review, Vol. 22 No 4, pp. 853-886.

Mueller, A., and Maes, J. (2015), “Arguments for biodiversity conservation in Natura 2000 sites: An analysis based on LIFE projects", Nature Conservation, Vol. 12 No 1, pp. 1-26.

Naess, A. (1973), "The shallow and the deep, long-range ecology movement. A summary", Inquiry, Vol. 16 No 1-4, pp. 95-100.

Northamptonshire Biodiversity Partnership (2008), Northamptonshire Biodiversity Action Plan, available at: http://www.northamptonshire.gov.uk/en/councilservices/Environ/planning/policy/natural/Doc uments/PDF\%20Documents/J27_Northamptonshire_Biodiversity_Action_Plan[1].pdf.

Norton, B. (1994), Towards Unity amongst Environmentalists, Oxford University Press, Oxford.

Pallot, J. (1992), "Elements of a theoretical framework for public sector accounting", Accounting, Auditing and Accountability Journal, Vol. 5 No. 1, pp. 38-57.

Parker, L., and Gould, G. (1999), "Changing public sector accountability: critiquing new directions", Accounting forum, Vol. 23 No. 2, pp. 109-135.

Regan, T. (1983), The Case for Animal Rights, Routledge, London.

Rimmel, G., and Jonäll, K. (2013), "Biodiversity reporting in Sweden: corporate disclosure and preparers' views", Accounting, Auditing \& Accountability Journal, Vol. 26 No 5, pp. 746-778.

Rolston III, H. (1985), “Valuing wildlands”, Environmental Ethics, Vol. 7 No 1, pp. 23-48.

Rolston III, H. (1988), "Human values and natural systems", Society \& Natural Resources, Vol. 1 No 1, pp. 269-283.

Rotherham Council (2004), Rotherham's Biodiversity Action Plan, available at: http://www.rotherham.gov.uk/corestrategyexamination/downloads/file/432/leb26_rotherham _biodiversity_action_plan_2004

Saegert, S., and Winkel, G.H. (1990), "Environmental psychology", Annual review of psychology, Vol. 41 No 1, pp. 441-477. 
Saint Helens Council (2006), Policy for Nature. A biodiversity action plan for St.Helens, available at http://old.sthelens.gov.uk/media/157592/policy_for_nature__a_biodiversity_action_plan_for_st_helens.pdf

Samkin, G., Schneider, A. and Tappin, D. (2014), "Developing a reporting and evaluation framework for biodiversity", Accounting, Auditing \& Accountability Journal, Vol. 27 No 3, pp. 527-562.

Schneider, A., Samkin, G., and Davey, H. (2014), "Biodiversity reporting by New Zealand local authorities: the current state of play", Sustainability Accounting, Management and Policy Journal, Vol 5 No 4, pp. 425-456.

Siddiqui, J. (2013), "Mainstreaming biodiversity accounting: potential implications for a developing economy", Accounting, Auditing \& Accountability Journal, Vol. 26 No 5, pp. 779-805.

Singer, P. (1976), Animal Liberation, London: Jonathan Cape.

Somerset Biodiversity Partnership (2008), Wild Somerset, The Somerset Biodiversity Strategy 2008-2018, available at http://www.somerset.gov.uk/policies-andplans/strategies/biodiversity/

Soulé, M.E. (1985), “What is conservation biology?”, Bioscience, Vol. 35, pp. 727-734.

Sylvan, R. (1985), “A critique of deep ecology”, Radical Philosophy, Vol. 40, pp. 2-12

Sylvan, R. and Bennett, D. (1994), The Greening of Ethics, White Horse Press, Cambridge.

Thomas, D.R. (2006), "A general inductive approach for analyzing qualitative evaluation data", American Journal of Evaluation, Vol. 27 No 2, pp. 237-246.

Thomson, I., and Bebbington, J. (2005), "Social and environmental reporting in the UK: a pedagogic evaluation", Critical Perspectives on Accounting, Vol. 16 No 5, pp. 507-533.

Tregidga, H. (2013), "Biodiversity offsetting: problematisation of an emerging governance regime", Accounting, Auditing \& Accountability Journal, Vol. 26 No 5, pp. 806-832.

Union for Ethical BioTrade (2016), Biodiversity Barometer, available at http://ethicalbiotrade.org/dl/Baro-2016-web.pdf

UK Biodiversity Action Plan Steering Group (1994), Biodiversity: the UK Action Plan, Her Majesty's Stationery Office, London.

UK Biodiversity Steering Group (1995a), Biodiversity: The UK Steering Group Report. In Volume 1: Meeting the Rio Challenge, Her Majesty's Stationery Office, London.

UK Biodiversity Steering Group (1995b), Biodiversity: The UK Steering Group Report: Volume 2: Action Plans, Her Majesty's Stationery Office, London. 
UK Local Issues Advisory Group (1997), Guidance for Local Biodiversity Action Plans Guidance Notes 1 - 5, UK Local Issues Advisory Group, London.

van Liempd, D., and Busch, J. (2013), "Biodiversity reporting in Denmark", Accounting, Auditing \& Accountability Journal, Vol 26 No 5, pp. 833-872.

Vincent, A. (1993) "The Character of Ecology", Environmental Politics, Vol. 2 No 2, pp. 248-76.

Waltham Forest Council (2011), Waltham Forest Biodiversity Action Plan, available at: https://branding.walthamforest.gov.uk/Documents/wf-bap-30jun11.pdf

Weber, R.P. (1990), Basic Content Analysis, 2nd ed., Sage University Paper Series on Quantitative Applications in the Social Sciences No. 49, Sage, Newbury Park, CA.

Wells, D. (1993), "Green politics and environmental ethics: A defence of human welfare ecology", Politics, Vol. 28 No 3, pp. 515-527.

Wenz, P.S. (1988), Environmental justice, SUNY Press, New York, NY.

Williams, D.R., and Patterson, M.E. (1996), "Environmental meaning and ecosystem management: Perspectives from environmental psychology and human geography”, Society \& Natural Resources, Vol. 9 No 5, pp. 507-521. 
Figure 1 - Theoretical Framework

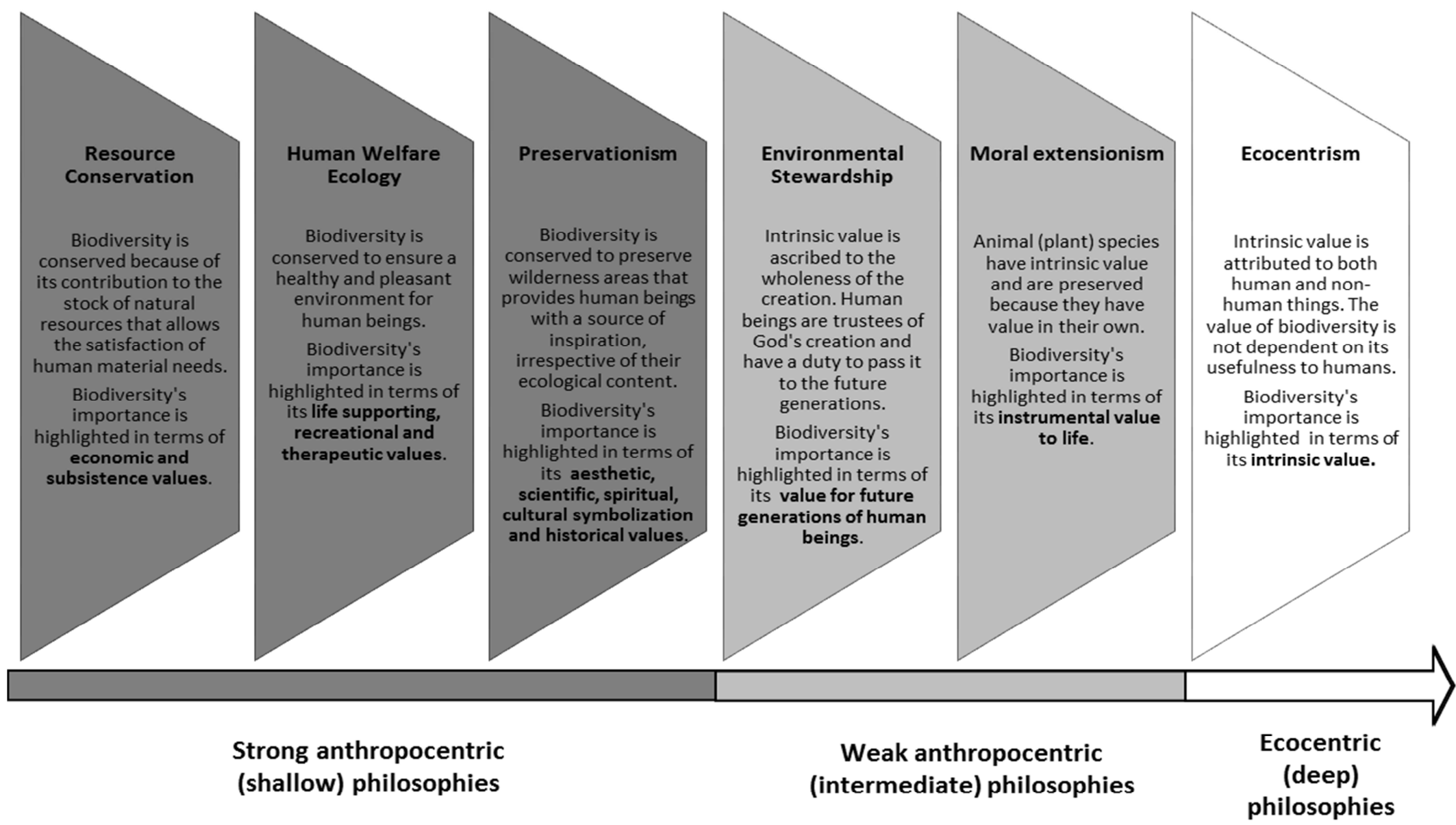


Figure 2 - Trends of disclosure of biodiversity's importance

$\%$ of narratives on biodiversity's importance

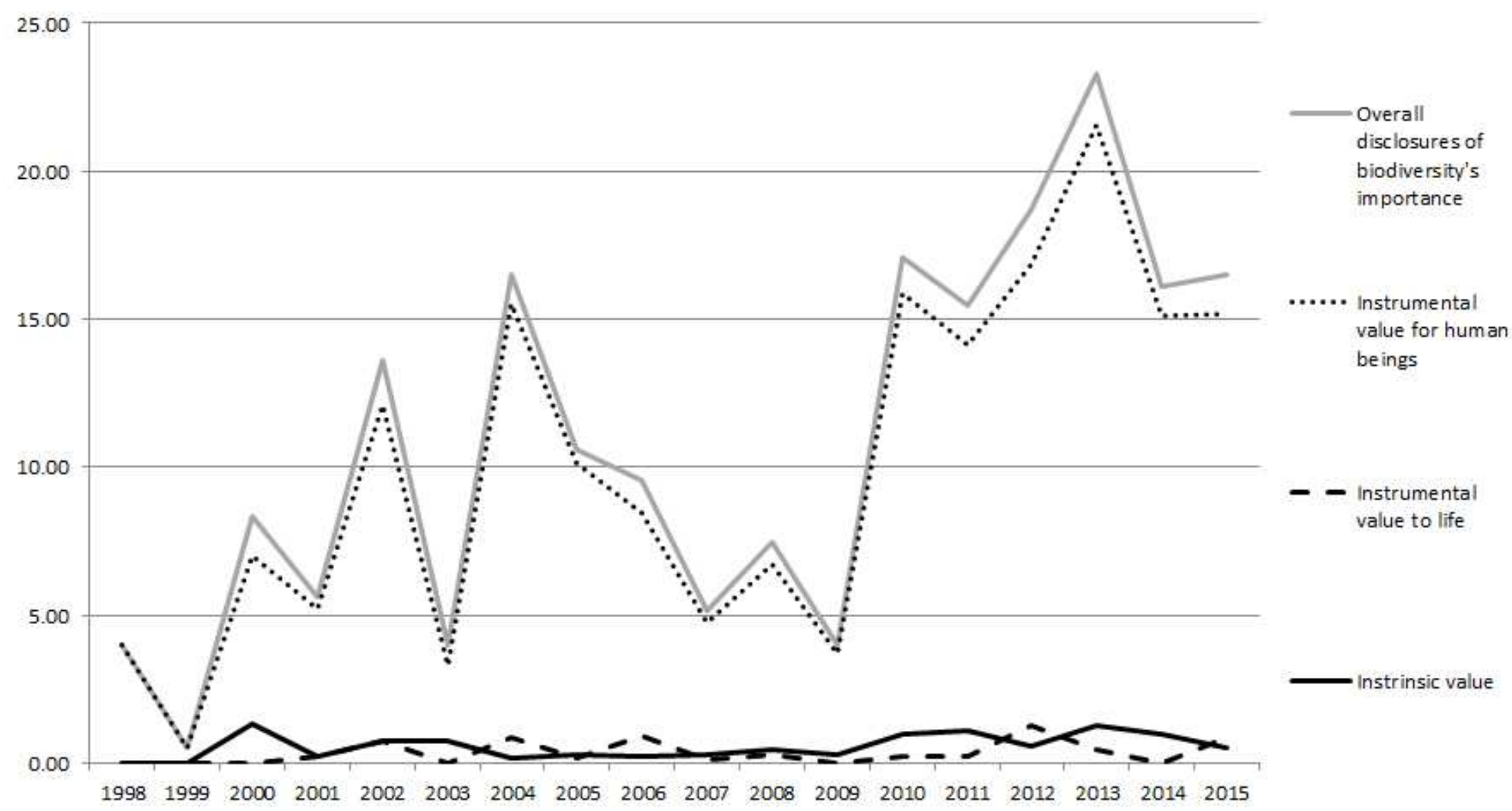


Table 1 - Biodiversity values

\begin{tabular}{|c|c|}
\hline \multicolumn{2}{|c|}{ PANEL A: INSTRUMENTAL VALUES TO HUMAN BEINGS } \\
\hline Economic value & $\begin{array}{l}\text { Biodiversity supports our economy. Without the products and services provided by the } \\
\text { natural environment, human beings would not be able to survive and prosper (Rolston III, } \\
\text { 1985, 1988). Many industrial sectors depend on biodiversity. It provides a wide range of } \\
\text { materials derived from plants and animals useful for agriculture, fisheries, forestry, building } \\
\text { industries and tourism. }\end{array}$ \\
\hline $\begin{array}{l}\text { Subsistence } \\
\text { value }\end{array}$ & $\begin{array}{l}\text { Biodiversity provides goods (such as water, food and raw materials to fabricate clothes etc.) } \\
\text { and services (such as natural energy to warm water and homes) which are necessary to fulfil } \\
\text { all basic human needs. }\end{array}$ \\
\hline $\begin{array}{l}\text { Life supporting } \\
\text { value }\end{array}$ & $\begin{array}{l}\text { Biodiversity supports the functions provided by ecosystems services upon which human } \\
\text { being survival depends and contributes to the maintenance of a healthy environment, by } \\
\text { providing clean air, water and soil and regulating essential ecological processes. }\end{array}$ \\
\hline $\begin{array}{l}\text { Recreational } \\
\text { value }\end{array}$ & $\begin{array}{l}\text { Biodiversity provides human beings with outdoor recreational opportunities. People enjoy } \\
\text { outdoor sports, such as hunting, fishing and skiing or simply experiencing nature by walking } \\
\text { in an ancient wood, watching and photographing wildlife. These experiences enrich human } \\
\text { lives and provide them with a sense of wellbeing (Hartig et al. 1991). }\end{array}$ \\
\hline $\begin{array}{l}\text { Therapeutic } \\
\text { value }\end{array}$ & $\begin{array}{l}\text { Biodiversity contributes to physical and mental wellbeing. Nature is an ideal setting to treat } \\
\text { mental illness and improve physical health. It helps us to recover from stress and mental } \\
\text { fatigue, improve concentration and prevent disease (Rolston III, 1985). }\end{array}$ \\
\hline $\begin{array}{l}\text { Educational } \\
\text { value }\end{array}$ & $\begin{array}{l}\text { Nature and open-spaces are means that can be used to educate people. They stimulate } \\
\text { learning processes such as risk calculation and orientation and teach humans to take care of } \\
\text { their physical condition. It develops the virtues of humility, simplicity, frugality, serenity and } \\
\text { independence (Rolston III, 1985, 1988). }\end{array}$ \\
\hline Aesthetic value & $\begin{array}{l}\text { The aesthetic value of biodiversity refers to the enjoyment that human beings obtain from } \\
\text { contact with natural and wild landscapes that they consider aesthetically pleasing and } \\
\text { delightful (Chapin III et al., 2000). }\end{array}$ \\
\hline Scientific value & $\begin{array}{l}\text { The variety of life on earth represents a living library of biology and a source of inspiration } \\
\text { and curiosity that can lead to scientific discoveries. Our society gains knowledge from } \\
\text { biodiversity, which contributes to expand our understanding of the world (Rolston III, 1985). }\end{array}$ \\
\hline Spiritual value & $\begin{array}{l}\text { Human beings are willing to preserve biodiversity to respect religious beliefs. Some religions } \\
\text { attribute spiritual values to natural sites (e.g. sacred groves, sites of worship, rituals and } \\
\text { offerings, burial sites, etc.), animals (e.g. hinduism gives a significant religious meaning to } \\
\text { cattle) or plants and other natural elements. }\end{array}$ \\
\hline $\begin{array}{l}\text { Cultural- } \\
\text { symbolization } \\
\text { value }\end{array}$ & $\begin{array}{l}\text { Human-beings feel a moral obligation toward natural things that have cultural significance } \\
\text { for them or that remind them of important personal experiences. For example, the maple leaf } \\
\text { for Canada, the Cedar tree for Lebanon, or the bald eagle, that symbolizes self-images and } \\
\text { aspirations for US Americans, are iconic national symbols. }\end{array}$ \\
\hline Historical value & $\begin{array}{l}\text { The natural heritage is inextricably bound up with the history of a community. Natural places } \\
\text { might have historical values as they were locations for events of historical importance such } \\
\text { as battle sites, memorials and ruins. }\end{array}$ \\
\hline Future value & $\begin{array}{l}\text { The future value of biodiversity refers to the need of preserving biodiversity to ensure that } \\
\text { future generations will receive a natural environment as rich and varied as the current one } \\
\text { (Jones, 2003). }\end{array}$ \\
\hline \multicolumn{2}{|c|}{ PANEL B - NON-INSTRUMENTAL VALUES } \\
\hline $\begin{array}{l}\text { Instrumental } \\
\text { value to life }\end{array}$ & $\begin{array}{l}\text { Biodiversity is valuable because it supports the life of other living things such as animals and } \\
\text { plants (Attfield, 1983; Regan, 1983; Singer 1976). }\end{array}$ \\
\hline Intrinsic value & $\begin{array}{l}\text { Biodiversity is valuable simply because it exists, regardless of its usefulness for human } \\
\text { beings (Naess, 1973). }\end{array}$ \\
\hline
\end{tabular}


Table 2 - Descriptive statistics on 143 UK LBAPs analysed

\begin{tabular}{|c|c|c|c|c|c|c|c|c|c|c|c|}
\hline $\begin{array}{c}\text { Year of } \\
\text { publication }\end{array}$ & $\begin{array}{c}\text { No of } \\
\text { LBAPs }\end{array}$ & $\begin{array}{l}\text { Average } \\
\text { no of } \\
\text { LBAP's } \\
\text { pages }\end{array}$ & $\begin{array}{l}\text { Average } \\
\text { no of } \\
\text { LBAP's } \\
\text { sentences }\end{array}$ & $\begin{array}{l}\text { Average } \\
\text { no of } \\
\text { LBAP's } \\
\text { words }\end{array}$ & $\begin{array}{l}\% \text { of LBAPs that } \\
\text { include the need } \\
\text { to raise awareness } \\
\text { of biodiversity's } \\
\text { importance as one } \\
\text { main objective }\end{array}$ & $\begin{array}{l}\% \text { of LBAPs } \\
\text { that explain } \\
\text { biodiversity's } \\
\text { importance }\end{array}$ & $\begin{array}{l}\% \text { of LBAPs } \\
\text { with a } \\
\text { section on } \\
\text { biodiversity's } \\
\text { importance }\end{array}$ & $\begin{array}{l}\text { Average no } \\
\text { of sentences } \\
\text { on } \\
\text { biodiversity's } \\
\text { importance }\end{array}$ & $\begin{array}{c}\% \text { of } \\
\text { sentences on } \\
\text { biodiversity's } \\
\text { importance }\end{array}$ & $\begin{array}{l}\text { Average no } \\
\text { of words on } \\
\text { biodiversity's } \\
\text { importance }\end{array}$ & $\begin{array}{c}\% \text { of words } \\
\text { on } \\
\text { biodiversity's } \\
\text { importance }\end{array}$ \\
\hline 1998 & 4 & 73.75 & $2,490.33$ & $22,487.75$ & 100.00 & 50.00 & 50.00 & 4.00 & 0.16 & 66.25 & 0.29 \\
\hline 1999 & 2 & 21.00 & 276.00 & $5,784.00$ & 50.00 & 50.00 & 0 & 0.50 & 0.18 & 16.50 & 0.29 \\
\hline 2000 & 3 & 115.33 & $2,412.00$ & $35,042.00$ & 66.67 & 66.67 & 33.33 & 8.33 & 0.35 & 191.67 & 0.55 \\
\hline 2001 & 5 & 50.00 & 809.80 & $14,417.00$ & 80.00 & 60.00 & 20.00 & 2.40 & 0.30 & 59.20 & 0.41 \\
\hline 2002 & 8 & 112.00 & $1,924.75$ & $38,155.63$ & 87.50 & 100.00 & 62.50 & 17.63 & 0.92 & 269.00 & 0.71 \\
\hline 2003 & 7 & 103.29 & $1,861.43$ & $26,927.14$ & 100.00 & 71.43 & 57.14 & 6.43 & 0.35 & 120.43 & 0.45 \\
\hline 2004 & 6 & 139.67 & $5,303.20$ & $46,979.20$ & 100.00 & 83.33 & 50.00 & 14.33 & 0.27 & 300.50 & 0.64 \\
\hline 2005 & 7 & 53.86 & 698.00 & $15,894.57$ & 100.00 & 100.00 & 28.57 & 10.57 & 1.51 & 216.86 & 1.36 \\
\hline 2006 & 10 & 111.70 & $2,364.50$ & $40,240.10$ & 100.00 & 70.00 & 70.00 & 8.00 & 0.34 & 178.90 & 0.44 \\
\hline 2007 & 8 & 52.25 & 583.63 & $12,773.63$ & 100.00 & 87.50 & 62.50 & 6.75 & 1.16 & 151.38 & 1.19 \\
\hline 2008 & 15 & 66.00 & 907.33 & $19,016.27$ & 93.33 & 80.00 & 40.00 & 11.33 & 1.25 & 187.40 & 0.99 \\
\hline 2009 & 7 & 62.86 & $1,960.57$ & $23,278.86$ & 85.71 & 42.86 & 42.86 & 4.29 & 0.22 & 68.71 & 0.30 \\
\hline 2010 & 22 & 63.55 & 987.77 & $18,717.55$ & 90.91 & 86.36 & 50.00 & 17.08 & 1.73 & 319.98 & 1.71 \\
\hline 2011 & 9 & 89.22 & $1,698.89$ & $26,120.44$ & 77.78 & 66.67 & 55.56 & 14.33 & 0.84 & 343.78 & 1.32 \\
\hline 2012 & 7 & 73.29 & $1,017.00$ & $19,362.00$ & 100.00 & 100.00 & 42.86 & 14.71 & 1.45 & 308.14 & 1.59 \\
\hline 2013 & 7 & 103.71 & $1,866.86$ & $28,639.14$ & 100.00 & 100.00 & 71.43 & 17.29 & 0.93 & 410.14 & 1.43 \\
\hline 2014 & 10 & 37.60 & 488.50 & $9,009.60$ & 100.00 & 90.00 & 60.00 & 16.60 & 3.40 & 355.10 & 3.94 \\
\hline \multirow[t]{2}{*}{2015} & 6 & 81.00 & $1,353.50$ & $22,410.33$ & 83.33 & 100.00 & 83.33 & 15.67 & 1.16 & 302.25 & 1.35 \\
\hline & 143 & 77.16 & $1,453.90$ & $23,090.46$ & 92.31 & 81.12 & 51.75 & 12.10 & $\mathbf{0 . 8 3}$ & 240.45 & 1.04 \\
\hline
\end{tabular}


Table 3 - Classification of biodiversity narratives into the categories of biodiversity values.

\begin{tabular}{|c|c|c|c|c|}
\hline & $\begin{array}{c}\text { No LBAPs } \\
\text { that mentioned } \\
\text { the value }\end{array}$ & $\begin{array}{l}\text { \% LBAPs that } \\
\text { mentioned the } \\
\text { value }\end{array}$ & $\begin{array}{c}\text { Average no of } \\
\text { sentences* }\end{array}$ & $\begin{array}{c}\text { Average no of } \\
\text { sentence** }\end{array}$ \\
\hline Life supporting value & 85 & 59.44 & 4.88 & 2.90 \\
\hline Economic value & 81 & 56.64 & 3.62 & 2.02 \\
\hline Recreational value & 65 & 45.45 & 1.84 & 0.84 \\
\hline Therapeutic value & 59 & 41.26 & 3.39 & 1.43 \\
\hline Future value & 51 & 35.66 & 1.92 & 0.69 \\
\hline Intrinsic value & 48 & 33.57 & 1.89 & 0.63 \\
\hline Subsistence value & 41 & 28.67 & 1.76 & 0.51 \\
\hline Cultural symbolization value & 35 & 24.48 & 1.54 & 0.35 \\
\hline Educational value & 31 & 21.68 & 2.52 & 0.57 \\
\hline Aesthetic value & 31 & 21.68 & 1.35 & 0.29 \\
\hline Spiritual value & 26 & 18.18 & 0.98 & 0.18 \\
\hline Instrumental value to life & 23 & 16.08 & 2.22 & 0.36 \\
\hline Historical value & 11 & 7.69 & 3.82 & 0.30 \\
\hline Scientific value & 7 & 4.90 & 1.19 & 0.06 \\
\hline \multicolumn{5}{|l|}{ Other anthropological reasons } \\
\hline General anthropocentric value & 56 & 39.16 & 1.59 & 0.62 \\
\hline Legal value & 18 & 12.59 & 2.58 & 0.35 \\
\hline
\end{tabular}

No obs. 143

Notes: (*) Calculated considering only the documents in which the specific biodiversity value was mentioned Notes: (**) Calculated considering all the LBAPs analysed. 
Table 4 - Classification of biodiversity narratives into shallow, intermediate and deep paradigms.

\begin{tabular}{lrr}
\hline & $\begin{array}{r}\text { Total number } \\
\text { of sentences }\end{array}$ & $\begin{array}{r}\mathbf{\%} \text { of } \\
\text { sentences }\end{array}$ \\
\hline Resource conservation & $\mathbf{3 6 1}$ & $\mathbf{2 0 . 9 5}$ \\
\hline - Economic value & 289 & 16.77 \\
- Subsistence value & 72 & 4.18 \\
\hline Human welfare ecology & $\mathbf{7 3 8}$ & $\mathbf{4 2 . 8 4}$ \\
\hline - Life supporting value & 415 & 24.09 \\
- Recreational value & 119 & 6.91 \\
- Therapeutic value & 204 & 11.84 \\
\hline Preservationism & $\mathbf{1 6 7}$ & $\mathbf{9 . 6 9}$ \\
\hline - Aesthetic value & 42 & 2.44 \\
- Scientific value & 8 & 0.46 \\
- Spiritual value & 26 & 1.51 \\
- Cultural symbolization value & 49 & 2.84 \\
- Historical value & 42 & 2.44 \\
\hline Other anthropocentric positions & $\mathbf{2 1 9}$ & $\mathbf{1 2 . 7 1}$ \\
\hline - General anthropocentric value & 89 & 5.17 \\
- Legal value & 49 & 2.84 \\
- Educational value & 81 & 4.70 \\
\hline TOTAL SHALLOW PARADIGMS & $\mathbf{1 , 4 8 5}$ & $\mathbf{8 6 . 1 9}$ \\
\hline Environmental Stewardship & $\mathbf{9 8}$ & $\mathbf{5 . 6 9}$ \\
\hline - Future value & 98 & 5.69 \\
\hline Moral extensionism & $\mathbf{5 1}$ & $\mathbf{2 . 9 6}$ \\
\hline - Instrumental value to non-human things & 51 & 2.96 \\
\hline TOTAL INTERMEDIATE PARADIGMS & $\mathbf{1 4 9}$ & $\mathbf{8 . 6 5}$ \\
\hline Ecocentrism & $\mathbf{8 9}$ & $\mathbf{5 . 1 6}$ \\
\hline - Intrinsic value & 89 & 5.16 \\
\hline TOTAL DEEP PARADIGMS & $\mathbf{8 9}$ & $\mathbf{5 . 1 6}$ \\
\hline TOTAL NARRATIVES ON BIODIVESITY'S IMPORTANCE & $\mathbf{1 , 7 2 3}$ & $\mathbf{1 0 0 . 0 0}$ \\
\hline & & \\
\hline
\end{tabular}

